\title{
Environmental DNA detects Critically Endangered largetooth sawfish in the wild
}

\author{
Colin A. Simpfendorfer ${ }^{1, *}$, Peter M. Kyne ${ }^{2}$, Tansyn H. Noble ${ }^{1}$, Julie Goldsbury ${ }^{1}$, \\ Rose K. Basiita ${ }^{1}$, Rob Lindsay ${ }^{3}$, Amos Shields ${ }^{3}$, Camillus Perry ${ }^{4}$, Dean R. Jerry ${ }^{1}$ \\ ${ }^{1}$ Centre for Sustainable Tropical Fisheries and Aquaculture, and College of Marine and Environmental Sciences, \\ James Cook University, Townsville, Queensland 4811, Australia
}

${ }^{2}$ Research Institute for the Environment and Livelihoods, Charles Darwin University, Darwin 0909, Northern Territory, Australia ${ }^{3}$ Malak Malak Ranger Group, and ${ }^{4}$ Wudikupildiyerr Ranger Group, Northern Land Council, Darwin 0801, Northern Territory, Australia

\begin{abstract}
Environmental DNA (eDNA) is a relatively new tool for the detection of rare, threatened and invasive species in water bodies. In this study we investigated the utility of an eDNA approach in detecting the Critically Endangered largetooth sawfish Pristis pristis in freshwater habitats in northern Australia. Water samples were collected from large aquaria mesocosms containing largetooth sawfish and other aquatic species, and floodplain waterholes and the main river channel of the Daly River, Northern Territory. Water samples were filtered using a $20 \mu \mathrm{m}$ nylon filter. DNA was extracted from filters and analysed with PCR using species-specific mitochondrial cytochrome $c$ oxidase subunit I (COI) primers designed to amplify only largetooth sawfish DNA. PCR products were cleaned and the COI gene sequenced to confirm the species identity. Using 3 aquaria, with one containing a largetooth sawfish, this method positively identified sawfish only in the correct aquarium. In the field water samples, 7 of 8 floodplain waterholes produced a sawfish eDNA PCR product, while eDNA was not detected in the main river channel. Based on gillnet sampling and traditional ecological knowledge, largetooth sawfish were known to occur at half of the waterhole and floodplain sites that tested positive for sawfish eDNA. These results demonstrated that an eDNA approach to detecting largetooth sawfish can produce reliable outcomes and can be used as a survey tool to help with conservation efforts for this and other threatened elasmobranchs.
\end{abstract}

KEY WORDS: Pristis pristis · Threatened species · Daly River · Survey techniques

\section{INTRODUCTION}

Sawfishes (Family Pristidae) are the most threatened family of elasmobranch (sharks and rays) (Dulvy et al. 2014), with all 5 species listed on the IUCN Red List of Threatened Species as either Critically Endangered or Endangered (IUCN 2015). Limited observational data and expert opinion suggest that sawfish species are now extinct in at least 20 countries within their former distribution, and are possibly extinct in many more (Dulvy et al. 2016). Sawfishes are large (maximum adult sizes of 3.2 to $7.0 \mathrm{~m}$ ) enigmatic rays that occur in tropical and sub-

\footnotetext{
*Corresponding author: colin.simpfendorfer@jcu.edu.au
}

tropical coastal marine, estuarine and freshwater ecosystems. Their distinctive toothed rostrum makes them very susceptible to capture in fishing gear and this has been the main driver of population declines (Simpfendorfer 2000, Peverell 2005, Dulvy et al. 2016). A full understanding of the crisis confronting sawfish populations worldwide, and the means to implement recovery strategies for these species, is limited by the ability to accurately determine their remaining extant range, due to both their current rarity and occurrence in remote regions.

A variety of survey techniques have been applied to detect and report the presence of sawfishes in

() The authors 2016. Open Access under Creative Commons by Attribution Licence. Use, distribution and reproduction are unrestricted. Authors and original publication must be credited. 
order to inform conservation efforts. Visual observation is rarely useful with these taxa because of their preference for turbid habitats and their benthic nature. Traditional fishing surveys using fishing gear (gillnets, lines) have proved useful (Thorburn et al. 2007, Wiley \& Simpfendorfer 2007), but are time consuming, logistically difficult in remote areas, expensive and may not detect animals even if they are present. Public encounter data have also been used to determine the distribution and habitat associations of smalltooth sawfish Pristis pectinata in Florida (Poulakis \& Seitz 2004, Wiley \& Simpfendorfer 2010, Waters et al. 2014). This approach is less expensive, but relies on the distribution of observational effort, considerable outreach, the ability of the public to identify species correctly and their willingness to report encounters (particularly given the apprehension over reporting the capture of a listed protected species) to gather sufficient data (Wiley \& Simpfendorfer 2010). Targeted interviews with fishers have also been used to examine sawfish distribution and abundance (Leeney \& Poncelet 2015, Leeney \& Downing 2016). These types of survey have proved useful in determining the changes in the distribution and abundance of sawfishes over time and can be carried out with limited resources. However, they are not always able to collect data on the contemporary distribution because of the rarity of sawfishes in some locations. To enhance the availability of information on the distribution of sawfishes, further detection techniques that are reliable, relatively inexpensive and easy to implement need to be developed and tested.

Environmental DNA (eDNA) is a relatively new and emerging technique that detects trace amounts of DNA from an aquatic species within water samples taken from putative habitats (Ficetola et al. 2008, Rees et al. 2014, Thomsen \& Willerslev 2015). This technique has been applied to a range of species in a variety of aquatic systems from freshwater to marine. Its usefulness has been demonstrated in detecting rare, cryptic and threatened teleost fishes (e.g. Jerde et al. 2011, Janosik \& Johnston 2015, Sigsgaard et al. 2015). For rare species, detection rates using eDNA can be more effective and more efficient than documenting presence with traditional fish sampling techniques (Janosik \& Johnston 2015, Sigsgaard et al. 2015), although the approach should be viewed as complementing rather than replacing traditional surveys and monitoring methods (Thomsen \& Willerslev 2015). This technique has not been tested under field conditions on elasmobranchs, but may be an approach that will help inform assessment and conservation efforts for threatened species, such as sawfishes. Thus the purpose of this study was to test the utility and robustness of eDNA approaches to detecting an elasmobranch (the largetooth sawfish $P$. pristis) within its native habitat. Specific aims were to (1) test the ability of eDNA to detect largetooth sawfish in a controlled positive environment (an aquarium), (2) develop a sampling protocol that could be applied to the collection of water samples in often remote and difficult to sample locations and (3) demonstrate the ability of eDNA to detect largetooth sawfish in the wild (with a focus on freshwater floodplain habitat).

\section{MATERIALS AND METHODS}

\section{Study species}

The largetooth sawfish Pristis pristis once occurred worldwide in tropical freshwater, estuarine and coastal marine ecosystems, and is a large elasmobranch reaching at least $6.5 \mathrm{~m}$ in length (Dulvy et al. 2016). Juvenile largetooth sawfish inhabit freshwater sections of rivers and associated floodplains, and move into estuarine and marine systems as they mature (Thorburn et al. 2007, Kyne et al. 2013), although adults may also inhabit freshwater habitats in some areas (Thorson 1982a,b). Population numbers of the largetooth sawfish have declined due to excessive by-catch in fisheries, along with a loss of habitat. It has been estimated that the extent of species occurrence has contracted to $61 \%$ of its original area, and the species is confirmed to occur in only 20 of the 75 countries from which it was historically known (Dulvy et al. 2016). These dramatic population declines and range contractions have resulted in the species now being assessed as Critically Endangered on the IUCN Red List (Kyne et al. 2013). Northern Australia is one of the few regions where $P$. pristis still occurs in reasonable numbers (Peverell 2005, Morgan et al. 2011), making this species and location an ideal candidate to test the utility of eDNA approaches to detecting threatened elasmobranchs in the wild.

\section{eDNA sampling}

To determine the potential of eDNA to detect the presence of rare sawfish, we undertook a 2-step validation process. The first involved validation that our primers would detect the presence of sawfish eDNA in a dilute and mixed template control environment 
(aquaria trials), while the second evaluated detection from a natural river catchment (field trials).

\section{Aquaria trials}

To ensure the primer specificity and functionality in a mixed template water sample, water was collected from large aquarium tanks (3.2 million 1, 7000001 and 20000 l) containing the target species P. pristis as well as other marine animals (Reef HQ Aquarium, Townsville, Queensland). A total of 4 replicate samples were collected in 21 containers from each of 3 tanks, one containing a largetooth sawfish specimen and 2 containing no largetooth sawfish, but rays (e.g. giant shovelnose ray Glaucostegus typus), sharks (e.g. blacktip reef shark Carcharhinus melanopterus, scalloped hammerhead Sphyrna lewini, zebra shark Stegostoma fasciatum) and/or large numbers of marine fishes and tropical marine organisms ( $>100$ species). In addition, 1 negative control sample was included for each tank (distilled water in an identical container submerged in tank water). Back in the laboratory, water samples were filtered, and eDNA isolated and subjected to PCR (see 'Laboratory methods').

\section{Field trials}

The Daly River catchment (Fig. 1) lies in the Northern Territory of Australia with an area of $53000 \mathrm{~km}^{2}$, including an extensive area of seasonally inundated floodplain. The hydrology of the river is driven by a highly seasonal monsoonal pattern of flow, with $>90 \%$ of annual rainfall occurring in the wet monsoonal period (approximately November to April) (Webster et al. 2005, Warfe et al. 2011). During the wet season monsoon, inundation allows for the movement of fish from the main river channel onto the floodplain (Warfe et al. 2011). As water recedes in the dry monsoonal period (approximately May to October), fish, including P. pristis, retreat to isolated waterhole refugia, which may remain isolated for several months, until the system is reconnected in the following wet season (although interannual variability in rainfall can limit connectivity in some years). Based on indigenous traditional ecological knowledge of
P. pristis on the Daly River floodplain, gillnet surveys during 2012 to 2013 documented its occurrence in floodplain waterholes (P. M. Kyne unpubl. data). The Daly River floodplain was therefore selected as a suitable area to test the applicability of eDNA detection for $P$. pristis based on these records and the ease of access to floodplain waterholes during the dry season. All sampling was conducted towards the end of the dry season (between 30 September and 3 October 2014) to (1) ensure there was no likelihood of eDNA cross-contamination from other locations due to flooding events and (2) allow for eDNA degradation in systems where sawfish may have occurred prior to waterholes becoming isolated, but had left the system prior to the dry season. eDNA has been shown to persist in the water column for less than a day to several days (Barnes et al. 2014), thus allowing ample time for any residual eDNA to degrade before samples were collected.

In the field, 21 water samples were collected from several locations within the catchment, including 8 floodplain waterholes, 2 main-channel river sites (both immediately downstream of in-stream barriers where largetooth sawfish are known to occur in the dry season due to impeded upstream movement) and 1 control site (an artificial water supply lake within the Daly River catchment, but outside of the floodplain inundation area) (Figs. $1 \& 2$ ). Owing to the presence of estuarine crocodiles Crocodylus porosus, water samples were collected using an extended pole with the sampling container affixed to the distal end. A total of 5 replicate 21 water sam-

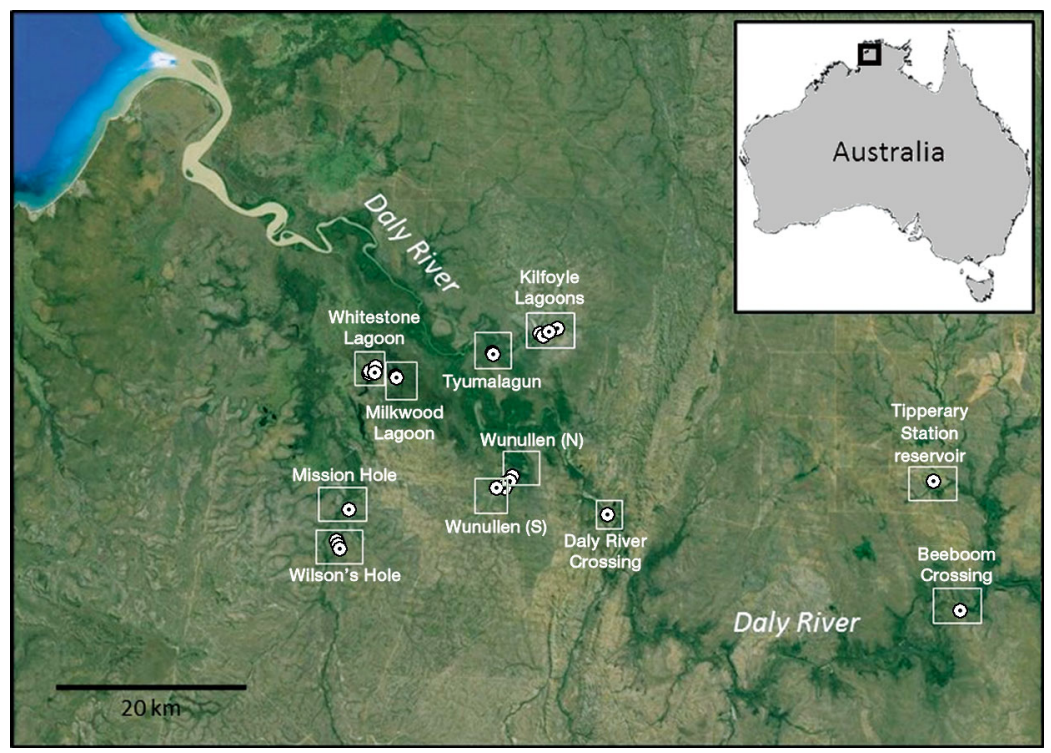

Fig. 1. Location of environmental DNA (eDNA) survey sites in the Daly River and associated floodplain, Northern Territory, Australia 

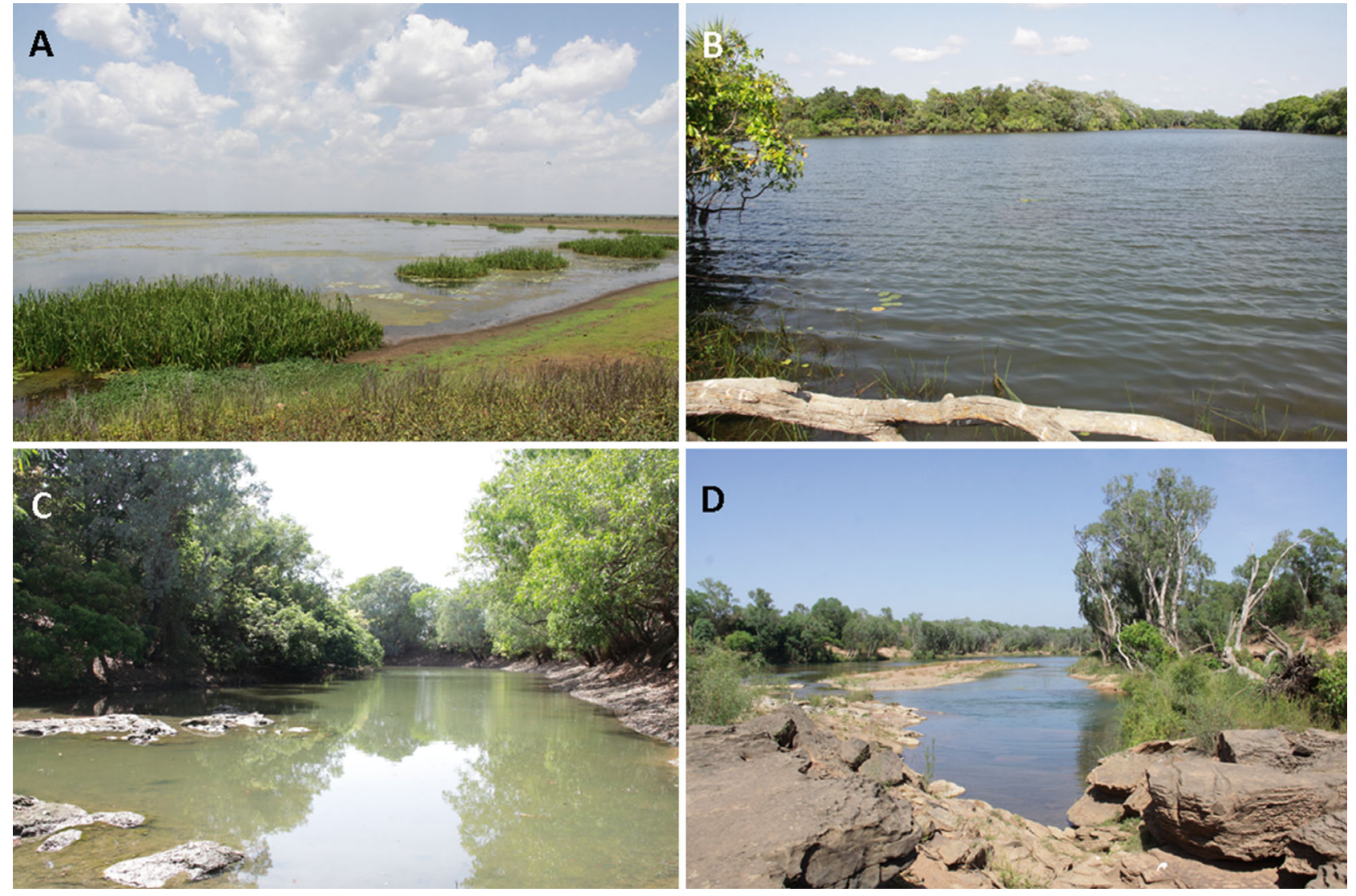

Fig. 2. Examples of Daly River floodplain waterholes and main-channel river sites (see Fig. 1) tested for the presence of largetooth sawfish Pristis pristis using eDNA. (A) Milkwood Lagoon, a shallow floodplain waterhole; (B) Mission Hole, a deep floodplain waterhole; (C) Kilfoyle Lagoons, a series of disconnected pools; and (D) Beeboom Crossing, a natural rock bar and artificial road crossing on the main-channel

ples were collected at each site, along with 1 negative control containing bleach-treated tap water, which was subjected to the same treatment as the sampling containers (i.e. a sealed container affixed to a pole and submerged into the water body). Water samples were cooled and stored on ice until filtering.

\section{Laboratory methods}

Filtration of water samples collected from aquaria and in the field followed a protocol adapted from Jerde et al. (2011). Water samples collected from aquaria were filtered in the laboratory (Molecular Ecology and Evolution Laboratory, Townsville, Queensland), while field samples were processed using a mobile filtering station. The filtering station comprised a filter funnel manifold (Pall Australia) connected with rubber tubing to a carboy for waste water discharge and a portable $230 \mathrm{~V}$ vacuum/pres- sure pump (Pall Australia), also connected to the carboy by separate tubing. Both aquaria and field samples were filtered within $10 \mathrm{~h}$ of collection using disposable micro-funnels (Pall Australia) and a $20 \mu \mathrm{m}$ nylon filter (Merck Millipore). To detect for DNA contamination of equipment, $500 \mathrm{ml}$ of commercial bottled water was passed through the filtering equipment (including the nylon filter that were kept and stored) prior to each sample being processed. On completion of filtration, filters containing eDNA were stored immediately, either at $-20^{\circ} \mathrm{C}$ (aquaria samples), or in absolute ethanol (field samples) until further analyses.

\section{Primer design}

Pristis spp.-specific gene primers (PZ-COI F1: 5'CCT CCT TCT ACT AGC CTC TGC C-3' and PZCOI R1: 5'-GGA AGA GATA CCA GCT AAG TGC AA-3') that amplified a $145 \mathrm{bp}$ section of the mtDNA 
cytochrome $c$ oxidase I (COI) gene were identified based on available sawfish sequences deposited in GenBank (www.ncbi.nlm.nih.gov) using the DNA primer design program SP-Designer V.6.5.0.0 (Villard \& Malausa 2013). Candidate primers were then compared using the Basic Local Alignment Search Tool (BLAST; www.ncbi.nlm.nih.gov/blast) function which performs in silico tests for specificity and nucleotide mismatches to other possible species in the National Center for Biotechnology Information (NCBI) database. Primers were found to be unique to the sequence of sawfish from the genus Pristis. To validate this, primers were also tested using PCR against DNA extracted from tissue samples from closely related sawfish species and other elasmobranchs that are known to inhabit the same water systems in northern Australia as largetooth sawfish (e.g. dwarf sawfish P. clavata, narrow sawfish Anoxypristis cuspidata, bull shark Carcharhinus leucas, speartooth shark Glyphis glyphis and northern river shark G. garricki). Primers were found to amplify DNA from specimens from only the genus Pristis, although only a weak product was found for P. clavata.

\section{DNA extraction and PCR}

DNA was extracted from filter papers using the ISOLATE II Genomic DNA Kit (Bioline, BIO-52067) following the manufacturer's instructions. Once eDNA was extracted, each sample was further treated using a DNA clean-up column (Bioline ISOLATE Fecal DNA Kit, BIO-52082) and then analysed via PCR for the presence or absence of largetooth sawfish DNA. PCR reaction chemistry and cycling conditions were as follows: $20 \mu$ total reaction volume, $2 \times$ Type-it Microsatellite PCR Kit (QIAGEN), largetooth sawfish COI primers (final concentration of $0.4 \mu \mathrm{M}$ each primer), $2 \mu \mathrm{l}$ of eDNA; PCR cycling conditions: initial denaturation at $95^{\circ} \mathrm{C}$ for $5 \mathrm{~min}$, followed by 35 cycles of $94^{\circ} \mathrm{C}$ for $30 \mathrm{~s}$ (denaturation) $/ 60^{\circ} \mathrm{C}$ for $90 \mathrm{~s}$ (annealing) $/ 72^{\circ} \mathrm{C}$ for $30 \mathrm{~s}$ (extension), and a final extension at $72^{\circ} \mathrm{C}$ for $10 \mathrm{~min}$. Positive control samples (either DNA extracted from largetooth sawfish tissue or, in the case of field samples, eDNA from aquarium tanks containing the target species) were included in each PCR run to ensure that all PCR conditions conducive to amplification of the target COI gene were met.

A total of 5 PCR replicates were analysed for each water sample. Whilst quantitative fluorescent-based PCR detection methodologies are usually more sensitive than gel-based methodologies, in the present study the presence of sawfish eDNA in samples was confirmed by running PCR amplicons on a $1.5 \%$ agarose gel. Amplicons, where present, were assumed to be sawfish DNA when a similar sized band to that from the positive samples was evident. To confirm this, amplicons were pin stabbed with a sterile needle and the pin placed into a tube to provide a template for a second round of PCR (conducted under the same conditions as previously described, except only 14 PCR cycles were used). Products were then cleaned with Sephadex G-50 (GE Healthcare) columns prior to forward and reverse strand Sanger sequencing. Returned sequences were then collated and compared against 7 locally generated COI largetooth sawfish sequence haplotypes (Feutry et al. 2015) using the local BLAST function in Geneious 8.0.5.

\section{Species identification}

The COI gene of the largetooth sawfish was subsequently sequenced in both forward and reverse directions. Each nucleotide sequence pair was aligned in Geneious 8.0.5 prior to a local BLAST against reference largetooth sawfish sequences. Only sequences that returned hits matching largetooth sawfish with a similarity of $100 \%$ pairwise identity were confirmed as positive for the species.

\section{RESULTS}

\section{Aquaria trials}

DNA was successfully PCR amplified using the species-specific COI primers from all aquaria water samples containing the largetooth sawfish specimen. No PCR products were evident from the other 2 tanks where largetooth sawfish Pristis pristis was absent. When PCR amplicons were sequenced, results confirmed that the amplified PCR product matched the largetooth sawfish reference COI sequence with exact nucleotide specificity. This confirmed that the eDNA COI marker was specific for largetooth sawfish and could be used to detect eDNA from the species in a complex and mixed DNA template sample.

\section{Field sampling}

Largetooth sawfish DNA was detected via the amplification of PCR products in many of the water samples collected from the Daly River catchment (Table 1). Positive detections were found in water 
Table 1. Largetooth sawfish Pristis pristis environmental DNA (eDNA) results for sampling locations in the Daly River catchment, Northern Territory, Australia. Previous records from sampling sites were based on previous gillnet surveys or indigenous traditional ecological knowledge (TEK). na: not applicable

\begin{tabular}{|lcccc|}
\hline Site & Site type & $\begin{array}{c}\text { P. pristis } \\
\text { records }\end{array}$ & $\begin{array}{c}\text { eDNA results } \\
\text { (positive/collected) }\end{array}$ & $\begin{array}{c}\text { Negative } \\
\text { control }\end{array}$ \\
\hline Mission Hole & Floodplain & None & $1 / 5$ & Passed \\
Wilson's Hole & Floodplain & None & $1 / 5$ & Passed \\
Milkwood Lagoon & Floodplain & None & $1 / 5$ & Passed \\
Whitestone Lagoon & Floodplain & None & $1 / 5$ & Passed \\
Daly River Crossing & River main-channel & Gillnet survey & $0 / 5$ & Passed \\
Kilfoyle Lagoons & Floodplain & TEK & $0 / 5$ & Passed \\
Tyumalagun & Floodplain & TEK & $2 / 5$ & Passed \\
Wunullen (north) & Floodplain & Gillnet survey & $1 / 5$ & Passed \\
Wunullen (south) & Floodplain & Gillnet survey & $3 / 5$ & Passed \\
Beeboom Crossing & River main-channel & Gillnet survey & $0 / 5$ & Passed \\
Tipperary Station reservoir & Artificial & na & $0 / 2$ & Passed \\
\hline
\end{tabular}

samples collected from Mission Hole, Wilson's Hole, Milkwood Lagoon, Whitestone Lagoon, Tyumalagun, Wunullen (north) and Wunellen (south). To confirm that the positive PCR detections were largetooth sawfish, amplicons from 2 sites were sequenced as before. An exact nucleotide match to the largetooth sawfish reference sequence was observed for all sequences tested from field samples. Control samples for each site tested negative, confirming there was no DNA contamination. Water samples collected from the control site (an artificial water supply lake) did not amplify a PCR product. Therefore, the results confirm the ability of the COI primers designed to detect the occurrence of largetooth sawfish eDNA where it was present.

\section{DISCUSSION}

The results of this study demonstrated eDNA as a powerful tool for detecting the presence of largetooth sawfish Pristis pristis in water samples collected from freshwater habitats. This is consistent with a rapidly growing body of research that is demonstrating the potential of eDNA as a survey technique for rare, threatened and invasive species in both freshwater (Jerde et al. 2011, Sigsgaard et al. 2015) and marine systems (Thomsen et al. 2012). To date, eDNA research on elasmobranchs has been restricted to testing its ability to detect species in a large marine aquarium (Kelly et al. 2014). The demonstration of the utility of this approach in the field suggests that it is an approach that has great potential to better understand the distribution of threatened sharks and rays, and to help target other survey and research approaches.
Remote tropical environments can present logistical challenges for eDNA sampling, but these can be overcome by designing appropriate water collection and filtering protocols. The study locations sampled in northern Australia had characteristics that presented a number of challenges including high temperature, high turbidity and a lack of refrigeration. Despite these challenges, a sampling methodology was implemented that allowed for the collection of samples that demonstrated the presence of the target species. However, the technique was not able to detect largetooth sawfish in the main river channel where fishing surveys indicate they occur (P. M. Kyne unpubl. data), possibly because of the high water flow and thus turnover rates present at these sites. Further research to determine effective ways to detect elasmobranch species in areas with high water turnover rates will further aid the development of broad-scale surveys. Similarly, the testing of this approach in estuarine and marine habitats would also contribute to increasing the scale of surveys for species such as largetooth sawfish that move between freshwater and marine areas (Thorburn et al. 2007, Morgan et al. 2011). While testing in marine aquaria has proven effective (present study and Kelly et al. 2014), developing effective collection and filtering techniques suitable for these habitats is still required.

The ability of the eDNA sampling to specifically identify largetooth sawfish from other elasmobranch species present in the aquarium test and the field sampling indicates that species-specific surveys are possible. The sequencing of a subset of positive PCR products confirmed the identifications and provided confidence in the results. The species specificity demonstrated means that it should be possible to 
develop tests for individual elasmobranch species that will help inform conservation actions. These may include broad-scale surveys to better understand distribution and abundance, regular monitoring to study changes in occurrence through time, or targeted sampling to determine if a species of interest may be affected by human activities (e.g. damming and construction of other in-stream barriers, water extraction, dredging).

The development of eDNA sampling of water for largetooth sawfish presents the possibility of implementing a broad-scale survey to provide greater understanding of its current distribution. Based on limited data and expert opinion, Dulvy et al. (2016) suggested that this species is possibly extinct in 50 countries in its former range, and drastically reduced in abundance throughout most of its current range. eDNA surveys could help confirm whether extinction has occurred on this level, whether there are other countries where localized extinction has occurred, and help identify areas with remnant populations where priority conservation action is required. This type of information will provide huge benefits to global conservation efforts for largetooth sawfish (Harrison \& Dulvy 2014). Similar approaches could also be developed for other sawfish species that have also declined in range and abundance, and face similar conservation challenges (Simpfendorfer 2000, Morgan et al. 2011, Dulvy et al. 2016), or indeed threatened elasmobranchs more generally (Dulvy et al. 2014). eDNA surveys will not replace other research and monitoring tools for sawfishes, but provide an additional powerful method that has the potential to improve conservation efforts.

Acknowledgements. This work was supported by the Tropical Ecosystems Hub, the Marine Biodiversity Hub and the Northern Australia Hub, collaborative partnerships supported through funding from the Australian Government's National Environmental Research Program (NERP). We are grateful to the Traditional Owners of the Malak Malak Land Trust, and Doug Chessen and Len Rule from the Australian Agricultural Company for access to sampling sites, Reef HQ in Townsville for allowing us to sample water from their commercial aquaria, and Pierre Feutry for providing largetooth sawfish sequences.

\section{LITERATURE CITED}

Barnes MA, Turner CR, Jerde CL, Renshaw MA, Chadderton WL, Lodge DM (2014) Environmental conditions influence eDNA persistence in aquatic systems. Environ Sci Technol 48:1819-1827

Dulvy NK, Fowler SL, Musick JA, Cavanagh RD and others (2014) Extinction risk and conservation of the world's sharks and rays. eLife 3:e00590

Dulvy NK, Davidson LNK, Kyne PM, Simpfendorfer CA, Harrison LR, Carlson JK, Fordham SV (2016) Ghosts of the coast: global extinction risk and conservation of sawfishes. Aquat Conserv 26:134-153

Feutry P, Kyne PM, Pillans RD, Chen X, Marthick JR, Morgan DL, Grewe PM (2015) Whole mitogenome sequencing refines population structure of the Critically Endangered sawfish Pristis pristis. Mar Ecol Prog Ser 533: 237-244

Ficetola GF, Miaud C, Pompanon F, Taberlet P (2008) Species detection using environmental DNA from water samples. Biol Lett 4:423-425

Harrison LR, Dulvy NK (2014) Sawfish: a global strategy for conservation. International Union for the Conservation of Nature Species Survival Commission's Shark Specialist Group, Vancouver

IUCN (2015) The IUCN Red List of Threatened Species Version 2015.1. Available at www.iucnredlist.org (accessed 5 June 2015)

Janosik A, Johnston C (2015) Environmental DNA as an effective tool for detection of imperiled fishes. Environ Biol Fishes 98:1889-1893

Jerde CL, Mahon AR, Chadderton WL, Lodge DM (2011) "Sight-unseen" detection of rare aquatic species using environmental DNA. Conserv Lett 4:150-157

Kelly RP, Port JA, Yamahara KM, Crowder LB (2014) Using environmental DNA to census marine fishes in a large mesocosm. PLoS One 9:e86175

Kyne PM, Carlson J, Smith K (2013) Pristis pristis. The IUCN Red List of Threatened Species Version 2015.1. www.iucnredlist.org (accessed 5 June 2015)

> Leeney RH, Downing N (2016) Sawfishes in The Gambia and Senegal-shifting baselines over 40 years. Aquat Conserv 26:265-278

Leeney RH, Poncelet P (2015) Using fishers' ecological knowledge to assess the status and cultural importance of sawfish in Guinea-Bissau. Aquat Conserv 25: 411-430

Morgan DL, Whitty JM, Phillips NM, Thorburn DC, Chaplin JA, McAuley RB (2011) North-western Australia as a hotpot for endangered elasmobranchs with particular reference to sawfishes and the northern river shark. J R Soc West Aust 94:345-358

> Peverell SC (2005) Distribution of sawfishes (Pristidae) in the Queensland Gulf of Carpentaria, Australia, with notes on sawfish ecology. Environ Biol Fishes 73:391-402

Poulakis GR, Seitz JC (2004) Recent occurrence of the smalltooth sawfish, Pristis pectinata (Elasmobranchiomorphi: Pristidae), in Florida Bay and the Florida Keys, with comments on sawfish ecology. Fla Sci 67:27-35

Rees HC, Maddison BC, Middleditch DJ, Patmore JRM, Gough KC (2014) The detection of aquatic animal species using environmental DNA - a review of eDNA as a survey tool in ecology. J Appl Ecol 51:1450-1459

> Sigsgaard EE, Carl H, Møller PR, Thomsen PF (2015) Monitoring the near-extinct European weather loach in Denmark based on environmental DNA from water samples. Biol Conserv 183:46-52

> Simpfendorfer CA (2000) Predicting population recovery rates for endangered western Atlantic sawfishes using demographic analysis. Environ Biol Fishes 58:371-377

> Thomsen PF, Willerslev E (2015) Environmental DNA - an emerging tool in conservation for monitoring past and present biodiversity. Biol Conserv 183:4-18 
Thomsen PF, Kielgast J, Iversen LL, Møller PR, Rasmussen M, Willerslev E (2012) Detection of a diverse marine fish fauna using environmental DNA from seawater samples. PLoS One $7:$ :e41732

Thorburn DC, Morgan DL, Rowland AJ, Gill HS (2007) Freshwater sawfish Pristis microdon Latham, 1794 (Chondrichthyes: Pristidae) in the Kimberley region of Western Australia. Zootaxa 1471:27-41

Thorson TB (1982a) The impact of commercial exploitation on sawfish and shark populations in Lake Nicaragua. Fisheries 7:2-10

Thorson TB (1982b) Life-history implications of a tagging study of the largetooth sawfish, Pristis perotteti, in the Lake Nicaragua-Rio San Juan system. Environ Biol Fishes 7:207-228

Villard P, Malausa T (2013) SP-Designer: a user friendly program for designing species specific primer pairs from DNA sequence alignments. Mol Ecol Resour 13: 755-758

- Warfe DM, Pettit NE, Davies PM, Pusey BJ and others (2011)

Editorial responsibility: Mike Bruford, Cardiff, UK
The 'wet-dry' in the wet-dry tropics drives river ecosystem structure and processes in northern Australia. Freshw Biol 56:2169-2195

> Waters JD, Coelho R, Fernandez-Carvalho J, Timmers AA and others (2014) Use of encounter data to model spatiotemporal distribution patterns of endangered smalltooth sawfish, Pristis pectinata, in the western Atlantic. Aquat Conserv 24:760-776

Webster IT, Rea N, Padovan AV, Dostine P, Townsend SA, Cook S (2005) An analysis of primary production in the Daly River, a relatively unimpacted tropical river in northern Australia. Mar Freshw Res 56:303-316

Wiley TR, Simpfendorfer CA (2007) The ecology of elasmobranchs occurring in the Everglades National Park, Florida: implications for conservation and management. Bull Mar Sci 80:171-189

Wiley TR, Simpfendorfer CA (2010) Using public encounter data to direct recovery efforts for the endangered smalltooth sawfish Pristis pectinata. Endang Species Res 12: 179-191

Submitted: September 14, 2015; Accepted: March 21, 2016 Proofs received from author(s): April 30, 2016 